\title{
Vascular Toxicity of Cocaine
}

\author{
Sudeep Bansal ${ }^{1}$ and James P. Morgan ${ }^{2, *}$ \\ ${ }^{I}$ Division of Cardiovascular Medicine, Caritas Carney Hospital, ${ }^{2}$ Caritas St. Elizabeth Medical Center and Tufts Uni- \\ versity School of Medicine, Boston, MA 02135-2997, USA
}

\begin{abstract}
Cocaine acts on the vascular system by a number of mechanisms including monoamine re-uptake inhibition, local anesthesia, anti-cholinergic activity, alpha-adrenergic stimulation, regulation of various vasoconstrictor and vasodilator agents and promotion of prothrombotic state. These effects lead to a number of clinical syndromes via vasoconstriction, platelet activation, thrombus formation and early atherosclerosis in almost every organ of the body. Many of these effects may be under appreciated. Furthermore, cocaine is commonly associated with the use of tobacco and alcohol which can lead to superadditive effects and/or prolonged toxicity.
\end{abstract}

Keywords: Cocaine, vasoconstriction, platelet activation, atherosclerosis, infarction, cocaethylene, alcohol, nicotine.

\section{INTRODUCTION}

The cocoa plant (Erythroxylon coca) has been used of for centuries for its stimulant, euphorigenic and medicinal properties. The earliest records of its use, dates back to the ancient people of Peru and pre-Colombian Andean societies [1, 2].

In the $19^{\text {th }}$ century there were no laws regulating the sale of cocaine and therefore it was widely available. Coca cola and a number of other beverage manufacturers mixed cocaine in their drinks [1]. A number of prominent people are known to have used cocaine, including Sir Arthur Conan Doyle, Sigmund Freud and former US president Ulysses S. Grant [3].

The United Nations Office on Drugs and Crime (UNODC) estimated that 14 million people worldwide or $0.3 \%$ of the population aged $15-64$ used cocaine in 2005 . The largest number of cocaine users are in North America (6.4 million) followed by western and central Europe (3.9 million) and South America (including Central America and Caribbean: 2.2 million) (UNODC World Drug Report 2007, www.unodc.org). Currently cocaine is one of the most common illicit drugs used in North America (2005 National Survey on Drug Use \& Health, www.oas.samhsa.gov/nsduh ).

\section{PHARMACOLOGY}

Cocaine is an alkaloid extracted from the leaves of the Erythroxylon plant. This alkaloid is modified into various forms for consumption, the most common of which are crack and cocaine hydrochloride [4].

Cocaine is absorbed through mucous membranes and can therefore be snorted, inhaled, smoked or injected [5]. The time to reach peak plasma concentration depends on the method of consumption [4, 6], which is summarized in Table 1.

*Address correspondence to this author at the Caritas St. Elizabeth Medical Center, 736 Cambridge Street, Boston, MA 02135-2997, USA;

Email: James.Morgan@ caritaschristi.org
Nasal inhalation of cocaine delays the time to reach peak plasma concentration because of vasoconstriction of intranasal blood vessels. This leads to delayed and longer lasting euphorigenic effects than achieved with other routes of cocaine administration $[4,6]$.

Cocaine has a short half-life in plasma of about 30 to 90 min $[4,6]$. It is metabolized to methyl esters and benzoylecgonine by the liver and eliminated by the kidneys. Benzoylecgonine can be detected in urine 1-2 weeks after ingestion of cocaine. A small amount of cocaine is not metabolized and cleared as such by the kidney and, is detectable in urine for 4-6 $\mathrm{h}$ after consumption [4-7].

\section{Major Modes of Action:}

1) Monoamine re-uptake inhibitor: Responsible for sympathomimetic actions in the peripheral nervous system by inhibiting the re-uptake of catecholamines in presynaptic nerve terminals [8-12] and euphorigenic effects by inhibiting re-uptake of dopamine and serotonin in the central nervous system [13-15].

2) Local anesthesia: Cocaine competitively inhibits sodium channels in electrically active cells such as neurons and myocardium. This delays nerve conduction and thus decreases the ability to transmit impulses [16-19].

3) Anticholinergic action: Cocaine can inhibit muscarinic receptors in the heart $[20,21]$ and brain $[22,23]$. This action requires the concentration of cocaine to be about 20 times higher than that required to produce euphoria [24]. This concentration is generally not reached by inhalation or smoking. Anticholinergic toxicity of cocaine is seen in body packers when the ingested cocaine packets rupture, releasing large amounts of cocaine [25-27].

Cocaine has a number of other actions by which it may lead to toxic effects including alpha adrenergic stimulation $[28,29]$, increase in endothelin [30] and decrease in nitric oxide production [31]. 
Table 1. Forms of Cocaine and Time to Reach Peak Plasma Concentration

\begin{tabular}{|c|c|c|c|c|}
\hline Forms of Cocaine & Method of Consumption & Onset of Action & Peak Effect & Duration of Action \\
\hline \hline $\begin{array}{c}\text { Freebase } \\
\text { (Crack) }\end{array}$ & Inhalation (Smoking) & $3-5 \mathrm{sec}$ & $1-3 \mathrm{~min}$ & $5-15 \mathrm{~min}$ \\
\hline \multirow{2}{*}{\begin{tabular}{c} 
Cocaine hydrochloride \\
\cline { 2 - 5 }
\end{tabular}} & Intranasal (or other mucosal) & $10-60 \mathrm{sec}$ & $3-5 \mathrm{~min}$ & $20-60 \mathrm{~min}$ \\
\cline { 2 - 5 } & $15-20 \mathrm{~min}$ & $60-90 \mathrm{~min}$ \\
\hline
\end{tabular}

\section{VASCULAR EFFECTS OF COCAINE}

\section{Effect on Vascular Resistance}

Inhalation of cocaine leads to an early phase of vasodilatation followed by vasoconstriction [32]. The early vasodilatory action is attributed to its local anesthetic effect [33].

The generalized vasoconstrictor response is multifactorial and may be due to inhibition of neuronal re-uptake of catecholamines which leads to super-sensitivity to endogenous and exogenous norepinephrine. We have shown that the contractile response of ferret muscles is inhibited when they are pretreated with reserpine (Fig. (1)) [34]. This happens because reserpine depletes the synaptic vesicles of norepinephrine. Therefore, after cocaine administration, norepinephrine levels do not increase in the synaptic cleft leading to a blunted vasoconstrictor response.

Excess neurotransmitters in the alpha adrenergic $[28,29]$ and muscarinic nerve [35] endings mediate contraction of the blood vessels. Our experiments on porcine coronary artery demonstrate that the decrease in arterial diameter with coadministration of cocaine and prazosin (alpha receptor antagonist) is blunted [35]. Interestingly in the same experiment when we co-administered cocaine with atropine (anticholinergic agent) the vasoconstrictor response was inhibited much more than with prazosin (Fig. (2)). Therefore, we concluded that potentiation of both alpha adrenergic and muscarinic (M3 subtype) receptors are responsible for vasoconstrictive action of cocaine with the muscarinic pathway playing a greater role, especially in the coronary arterioles with a diameter of less than 200 micrometers, which are populated with the $\mathrm{M} 3$ receptor subtype [35].

Cocaine also produces vasoconstriction by increasing the production of endothelin-1 via stimulation of endothelial sigma receptors [30] and decreasing nitric oxide synthesis by the endothelial cells [31].

Chronic cocaine use reduces relaxation of vascular beds especially in the coronary micro-vasculation via down regulation of beta-adrenergic receptors and also by reduction of endothelium-dependent relaxation to serotonin [35].

The clinico-pathologic effects mediated by cocaine induced vasoconstriction include myocardial infarction [36, 37], stroke [38-40], mesenteric ischemia [41], renal infarction [42], gastric and duodenal ulceration and perforation [43].

\section{Effects on Platelets and Thrombus Formation}

Cocaine use is associated with enhanced platelet activation and aggregability, $[44,45]$ which may lead to thrombus

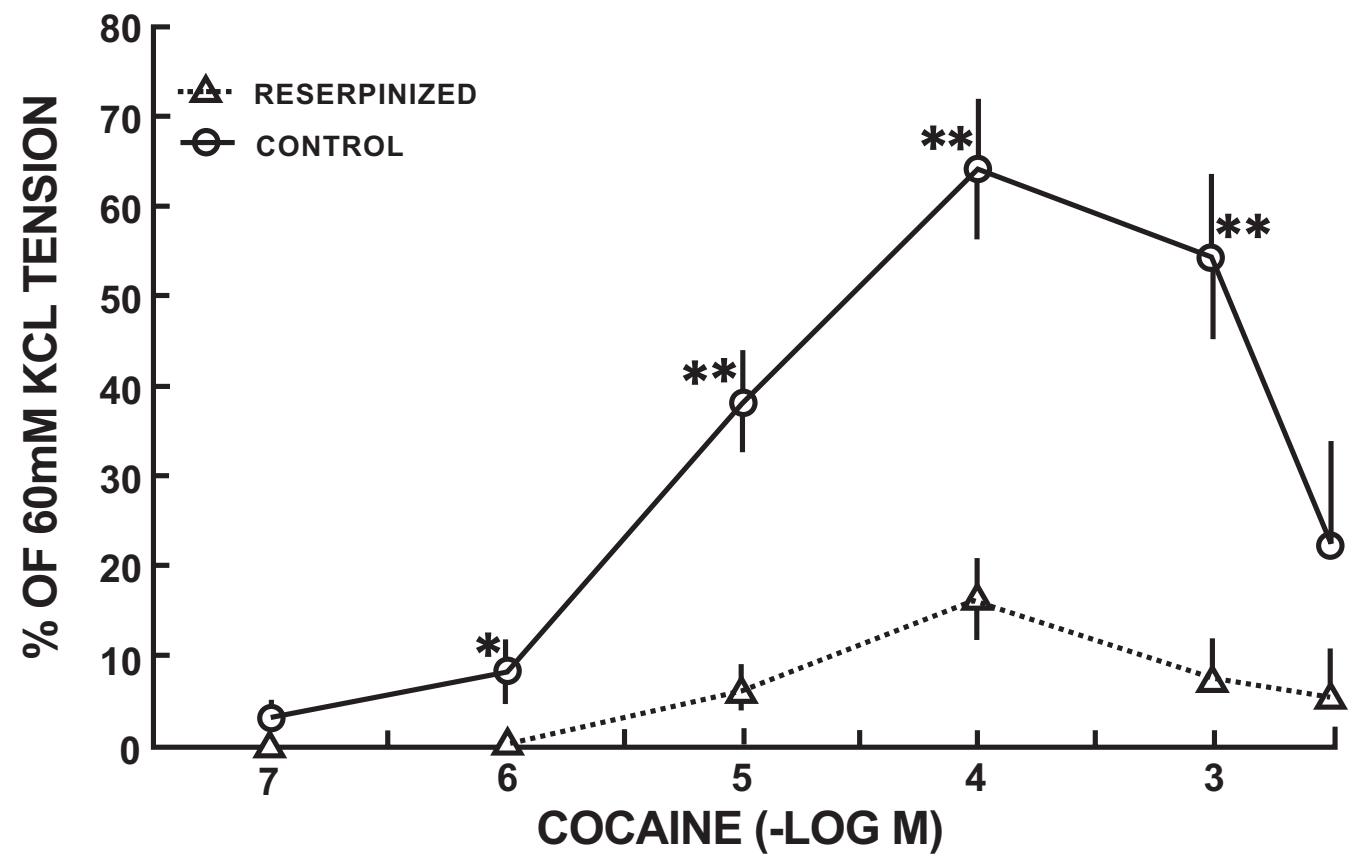

Fig. (1). Dose response relationship in control muscles and muscles pre-treated with reserpine. 
formation [46]. The demonstration of platelet rich thrombi in coronary arteries of patients undergoing fatal myocardial infarction gives credence to this theory [47]. Besides the coronary arteries, cocaine-mediated thrombosis has also been observed in the pulmonary [48], skin [49], peripheral [50] renal [42] and cerebral circulation [38-40].

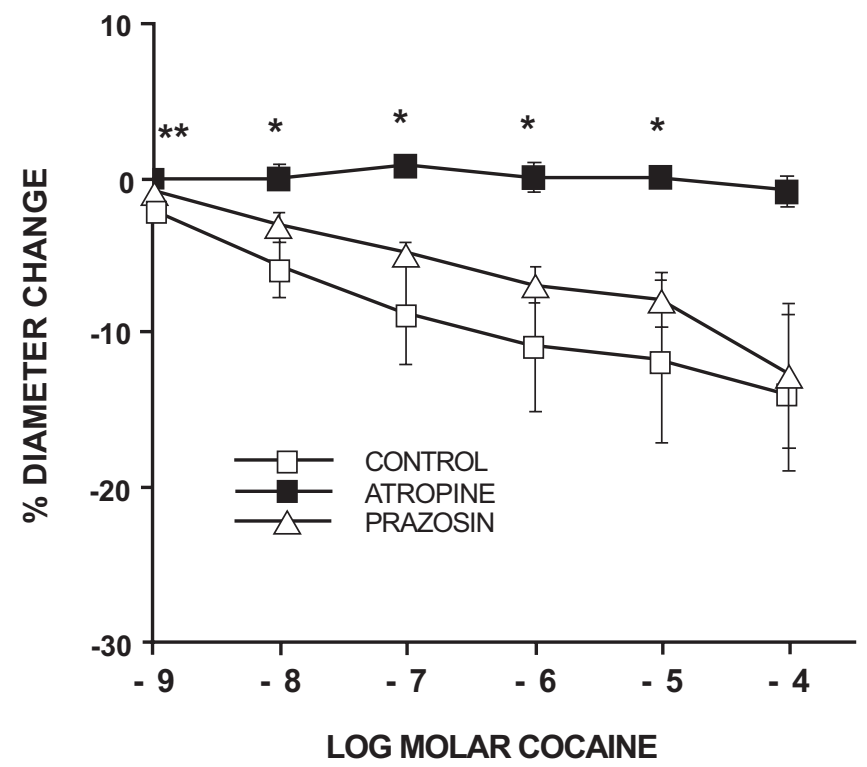

Fig. (2). Action of cocaine on porcine coronary microvessels with effect of co-administration of atropine (anticholinergic) and prazosin (alpha adrenergic antagonist).

The mechanism by which cocaine causes platelet activation is not clear. Cocaine induces the expression of P-selectin [51], release of alpha granule contents [44] and binding of fibrinogen to the platelet surface [44]. It may also enhance the degree of activation induced by other agonists, such as epinephrine, when present in sub-threshold concentrations [44].

Recently, Heesch et al. demonstrated that intranasal administration of cocaine $(2 \mathrm{mg} / \mathrm{kg})$ to drug naive healthy human volunteers led to platelet activation, alpha granule release, formation of platelet microaggregates and a slight decrease in bleeding time [52].

Besides platelet activation, cocaine also increases the plasma concentration of tissue plasminogen activator inhibitor [53], von Willibrand factor [54], blood viscosity (by increasing red blood cells) [54] and tissue factor levels [55]. There is a concomitant decrease in tissue factor pathway inhibitor [55]. These effects favor a prothrombotic state.

\section{VASCULAR INJURY AND ATHEROSCLEROSIS}

Cocaine can cause direct and indirect vascular injury leading to premature atherosclerosis [56, 57], aneurysmal dilatation [56] and aortic dissection [58].

Direct vascular injury may be mediated by increasing endothelial permeability to LDL [59], enhancing the expression of endothelial adhesion molecules leading to leukocyte migration [60] and proliferation of adventitial mast cells [57].

Indirect vascular injury may be mediated by cocaineinduced platelet activation that releases platelet-derived mitogens, including platelet-derived growth factor, epidermal growth factor, and transforming growth factor-beta, from platelet alpha-granules that may contribute to premature atherosclerosis [57, 61].

Cocaine has been shown to induce apoptosis in rat aortic smooth vascular cells [62] and human coronary artery endothelial cells [63]. These factors may also play a role in early atherosclerosis, weakening of vessel wall and formation of aneurysms. Hypertension due to cocaine use [32] may then lead to arterial dissection [58] and aneurysmal rupture [39, $56,64]$.

\section{Cocaine and Ethanol}

Concurrent use of cocaine and alcohol leads to formation of cocaethylene, a metabolite synthesized by transesterification in the liver [65]. In animals, cocaethylene has been shown to be more toxic than cocaine $[66,67]$. Cocaethylene shares the same molecular targets as cocaine [68] and because of its prolonged half life (cocaethylene, $2-4 \mathrm{~h} v s$. cocaine which is $30-90 \mathrm{~min}$ ) it may lead to persistent toxicity $[69,70]$. Cocaethylene inhibits the re-uptake of dopamine at the synaptic cleft $[66,68]$ and enhances microvascular permeability [71]. Our experiments demonstrated that cocaethylene is 10 -fold more potent than cocaine in decreasing peak intracellular calcium and myofilament responsiveness in ferret cardiac muscles to produce a negative inotropic effect [67].

Since humans are unable to distinguish the effect of cocaethylene from cocaine [72] it is speculated that in some cases the delayed toxicity caused by cocaine can be attributed to cocaethylene [73-77].

\section{Cocaine and Nicotine}

Cocaine consumption is commonly associated with cigarette smoking, alcohol and marijuana use [78]. People using tobacco, alcohol and marijuana have a $75 \%$ chance to try cocaine by a median age of 17 years [78]. Within minutes of cigarette smoking, nicotinic receptors in the adrenal medulla are stimulated, triggering the release of norepinephrine and epinephrine [79]. Nicotine has been shown to increase myocardial oxygen demand $[80,81]$ and cause vasoconstriction in angiographically normal and diseased segments of coronary arteries [82, 83]. Nicotine-induced vasoconstriction may be attributed to multiple mechanisms: 1) Potentiation of alpha adrenergic receptors similar to cocaine [84], 2) Injury to endothelial cells [85], and, 3) Reduction of prostacyclin formation [86, 87]. Therefore, the harmful effects of cocaine on myocardial oxygen supply and demand can be substantially exacerbated by cigarette smoking leading to an increased probability of acute coronary syndromes and ischemia in other organs.

\section{CONCLUSIONS}

Cocaine remains the most commonly abused drug responsible for emergency department visits to the hospital 
(Drug Abuse Warning Network (DAWN) Report - Oct 2002, www.oas.samhsa.gov). It causes a number of clinical syndromes due to its varied vascular insults including vasoconstriction, platelet activation and aggregation, thrombus formation and early atherosclerosis. The most common sequelae recognized is myocardial infarction. However, other clinical entities (Table 2) may be commonly missed or when recognized may not be attributed to cocaine use. The understanding of pathophysiologic mechanisms causing vascular toxicity in cocaine abusers is essential for the correct diagnoses, treatment and prevention of potentially lethal outcomes.

Table 2. Common Vascular Complications Caused by Cocaine Use and their Mechanism

\begin{tabular}{|c|c|}
\hline Clinical Syndrome & Mechanism \\
\hline $\begin{array}{l}\text { Myocardial Infarction }[36,37] \\
\text { Ischemic stroke [38-40] } \\
\text { Mesenteric Ischemia [41] } \\
\text { Renal infarction [42] } \\
\text { Pulmonary Infarction [48] }\end{array}$ & $\begin{array}{l}\text { Vasoconstriction } \\
\text { Platelet activation } \\
\text { Thrombus formation } \\
\text { Atherosclerosis } \\
\text { Plaque disruption }\end{array}$ \\
\hline $\begin{array}{l}\text { Intracranial hemorrhage }[39,64] \\
\text { Aortic Dissection }[56,58]\end{array}$ & $\begin{array}{c}\text { Hypertension } \\
\text { Aneurysm formation } \\
\text { Disruption of vascular muscle fibers }\end{array}$ \\
\hline $\begin{array}{l}\text { Gastric and duodenal ulcera- } \\
\text { tion/perforation [43] }\end{array}$ & $\begin{array}{l}\text { Vasoconstriction } \\
\text { Delayed gastric emptying via choliner- } \\
\text { gic activation leading to increased } \\
\text { exposure to hydrochloric acid }\end{array}$ \\
\hline $\begin{array}{l}\text { Nasal septal perforation [88] } \\
\text { Oropharyngeal ulcers [89] }\end{array}$ & $\begin{array}{l}\text { Vasoconstriction of local blood vessels } \\
\text { (due to inhalation or snorting cocaine) }\end{array}$ \\
\hline $\begin{array}{l}\text { Pulmonary interstitial and alveolar } \\
\text { hemorrhage [90] } \\
\text { Pulmonary edema }[91,92]\end{array}$ & $\begin{array}{l}\text { Direct vascular toxicity } \\
\text { Increased microvascular permeability } \\
\text { Increased pulmonary capillary pressure } \\
\text { Increased systemic vascular resistance }\end{array}$ \\
\hline $\begin{array}{l}\text { Rhabdomyolysis }[93,94] \\
\text { Acute renal failure }[93,94]\end{array}$ & $\begin{array}{c}\text { Vasoconstriction of intramuscular } \\
\text { arteries } \\
\text { Direct toxic effect } \\
\text { Tonic clonic seizures }\end{array}$ \\
\hline $\begin{array}{c}\text { Spontaneous abortion [95] } \\
\text { Abruptio placentae [96] } \\
\text { Prematurity, Intra-uterine growth } \\
\text { restriction [97] }\end{array}$ & $\begin{array}{c}\text { Vasoconstriction of placental vessels } \\
\text { Maternal hypertension }\end{array}$ \\
\hline
\end{tabular}

\section{REFERENCES}

[1] Das G. Cocaine abuse in North America: a milestone in history. J Clin Pharmacol 1993; 33: 267-73.

[2] Prakash A, Das G. Cocaine and the nervous system. Int J Clin Pharmacol Ther Toxicol 1993; 31: 575-81.

[3] Spillane JF. Cocaine: From Medical Marvel to Modern Menace in the United States, 1884-920 (Studies in Industry and Society). The Johns Hopkins University Press; 1999

[4] Benowitz NL. Clinical pharmacology and toxicology of cocaine. Pharmacol Toxicol 1993; 72: 3-2.

[5] Warner EA. Cocaine abuse. Ann Intern Med 1993; 119: 226-35.

[6] Fleming JA, Byck R, Barash PG. Pharmacology and therapeutic applications of cocaine. Anesthesiology 1990; 73: 518-31.

[7] Jeffcoat AR, Perez-Reyes M, Hill JM, Sadler BM, Cook CE. Cocaine disposition in humans after intravenous injection, nasal insuf- flation (snorting), or smoking. Drug Metab Dispos 1989; 17: 15359.

[8] Furchgott RF, Kirpekar SM, Rieker M, Schwab A. Actions and interactions of norepinephrine, tyramine and cocaine on aortic strips of rabbit and left atria of guinea pig and cat. J Pharmacol Exp Ther $1963 ; 142: 39-8$.

[9] Macmillan WH. A hypothesis concerning the effect of cocaine on the action of sympathomimetic amines. Br J Pharmacol Chemother 1959; 14: 385-91.

[10] Muscholl E. Effect of cocaine and related drugs on the uptake of noradrenaline by heart and spleen. Br J Pharmacol Chemother 1961; 16: 352-59.

[11] Trendelenburg U. The supersensitivity caused by cocaine. J Pharmacol Exp Ther 1959; 125: 55-5.

[12] Wise RA. Neural mechanisms of the reinforcing action of cocaine NIDA Res Monogr 1984; 50: 15-3.

[13] Kuhar MJ, Ritz MC, Boja JW. The dopamine hypothesis of the reinforcing properties of cocaine. Trends Neurosci 1991; 14: 29902 .

[14] Ritz MC, Lamb RJ, Goldberg SR, Kuhar MJ. Cocaine receptors on dopamine transporters are related to self-administration of cocaine. Science 1987; 237: 1219-223.

[15] Wise RA, Bozarth MA. A psychomotor stimulant theory of addiction. Psychol Rev 1987; 94: 469-92.

[16] Crumb WJJ, Clarkson CW. Characterization of cocaine-induced block of cardiac sodium channels. Biophys J 1990; 57: 589-99.

[17] Hille B. Local anesthetics: hydrophilic and hydrophobic pathways for the drug-receptor reaction. J Gen Physiol 1977; 69: 497-15.

[18] Przywara DA, Dambach GE. Direct actions of cocaine on cardiac cellular electrical activity. Circ Res 1989; 65: 185-92.

[19] Weidmann S. Effects of calcium ions and local anesthetics on electrical properties of Purkinje fibres. J Physiol 1955; 129: 56882 .

[20] Huang L, Woolf JH, Ishiguro Y, Morgan JP. Effect of cocaine and methylecgonidine on intracellular $\mathrm{Ca} 2+$ and myocardial contraction in cardiac myocytes. Am J Physiol 1997; 273: H893-01.

[21] Miao L, Qiu Z, Morgan JP. Cholinergic stimulation modulates negative inotropic effect of cocaine on ferret ventricular myocardium. Am J Physiol 1996; 270: H678-4.

[22] Flynn DD, Vaishnav AA, Mash DC. Interactions of cocaine with primary and secondary recognition sites on muscarinic receptors. Mol Pharmacol 1992; 41: 736-42.

[23] Sharkey J, Ritz MC, Schenden JA, Hanson RC, Kuhar MJ. Cocaine inhibits muscarinic cholinergic receptors in heart and brain. J Pharmacol Exp Ther 1988; 246: 1048-052.

[24] Schneider DJ. Cardiac ramifications of cocaine abuse. Coron Artery Dis 1991; 2: 267-73.

[25] Caruana DS, Weinbach B, Goerg D, Gardner LB. Cocaine-packet ingestion. Diagnosis, management, and natural history. Ann Intern Med 1984; 100: 73-4.

[26] Fishbain DA, Wetli CV. Cocaine intoxication, delirium, and death in a body packer. Ann Emerg Med 1981; 10: 531-2.

[27] Wetli CV, Mittlemann RE. The "body packer syndrome"-toxicity following ingestion of illicit drugs packaged for transportation. J Forensic Sci 1981; 26: 492-00.

[28] Kuhn FE, Johnson MN, Gillis RA, Visner MS, Schaer GL. Effect of cocaine on the coronary circulation and systemic hemodynamics in dogs. J Am Coll Cardiol 1990; 16: 1481-91.

[29] Lange RA, Cigarroa RG, Yancy CWJ, et al. Cocaine-induced coronary-artery vasoconstriction. N Engl J Med 1989; 321: 1557562.

[30] Wilbert-Lampen U, Seliger C, Zilker T, Arendt RM. Cocaine increases the endothelial release of immunoreactive endothelin and its concentrations in human plasma and urine: reversal by coincubation with sigma-receptor antagonists. Circulation 1998; 98: 38590.

[31] Mo W, Singh AK, Arruda JA, Dunea G. Role of nitric oxide in cocaine-induced acute hypertension. Am J Hypertens 1998; 11: 708-14.

[32] Benzaquen BS, Cohen V, Eisenberg MJ. Effects of cocaine on the coronary arteries. Am Heart J 2001; 142: 402-10.

[33] Ritchie JM, Greene NM. Local Anesthetics. In: Gilman AG, al. e, editors. Goodman and Gilman's The Pharmacologic Basis of Therapeutics. New York: Mcmillian Publishing Co; 1985; pp. 30221. 
[34] Egashira K, Morgan KG, Morgan JP. Effects of cocaine on excitation-contraction coupling of aortic smooth muscle from the ferret. $\mathbf{J}$ Clin Invest 1991; 87: 1322-28.

[35] Wang SY, Nunez BD, Morgan JP, Dai HB, Ross JN, Sellke FW. Cocaine and the porcine coronary microcirculation: effects of chronic cocaine exposure and hypercholesterolemia. J Cardiothorac Vasc Anesth 1995; 9: 290-6.

[36] Hollander JE, Hoffman RS. Cocaine-induced myocardial infarction: an analysis and review of the literature. J Emerg Med 1992; 10: 169-77.

[37] Coleman DL, Ross TF, Naughton JL. Myocardial ischemia and infarction related to recreational cocaine use. West J Med 1982; 136: 444-6.

[38] Kaku DA, Lowenstein DH. Emergence of recreational drug abuse as a major risk factor for stroke in young adults. Ann Intern Med 1990; 113: 821-7.

[39] Klonoff DC, Andrews BT, Obana WG. Stroke associated with cocaine use. Arch Neurol 1989; 46: 989-93.

[40] Levine SR, Washington JM, Jefferson MF, et al. "Crack" cocaineassociated stroke. Neurology 1987; 37: 1849-53.

[41] Mizrahi S, Laor D, Stamler B. Intestinal ischemia induced by cocaine abuse. Arch Surg 1988; 123: 394.

[42] Sharff JA. Renal infarction associated with intravenous cocaine use. Ann Emerg Med 1984; 13: 1145-7.

[43] Lee HS, LaMaute HR, Pizzi WF, Picard DL, Luks FI. Acute gastroduodenal perforations associated with use of crack. Ann Surg 1990; 211: 15-7.

[44] Kugelmass AD, Oda A, Monahan K, Cabral C, Ware JA. Activation of human platelets by cocaine. Circulation 1993; 88: 876-83.

[45] Rezkalla SH, Mazza JJ, Kloner RA, Tillema V, Chang SH. Effects of cocaine on human platelets in healthy subjects. Am J Cardiol 1993; 72: 243-6.

[46] Stenberg RG, Winniford MD, Hillis LD, Dowling GP, Buja LM. Simultaneous acute thrombosis of two major coronary arteries following intravenous cocaine use. Arch Pathol Lab Med 1989; 113: 521-4.

[47] Simpson RW, Edwards WD. Pathogenesis of cocaine-induced ischemic heart disease. Autopsy findings in a 21-year-old man. Arch Pathol Lab Med 1986; 110: 479-84.

[48] Delaney K, Hoffman RS. Pulmonary infarction associated with crack cocaine use in a previously healthy 23 -year-old woman. Am J Med 1991; 91: 92-4.

[49] Zamora-Quezada JC, Dinerman H, Stadecker MJ, Kelly JJ. Muscle and skin infarction after free-basing cocaine (crack). Ann Intern Med 1988; 108: 564-6.

[50] Lisse JR, Davis CP, Thurmond-Anderle M. Cocaine abuse and deep venous thrombosis [letter]. Ann Intern Med 1989; 110: 571-2.

[51] Kugelmass AD, Shannon RP, Yeo EL, Ware JA. Intravenous cocaine induces platelet activation in the conscious dog. Circulation 1995; 91: 1336-40.

[52] Heesch CM, Wilhelm CR, Ristich J, Adnane J, Bontempo FA, Wagner WR. Cocaine activates platelets and increases the formation of circulating platelet containing microaggregates in humans. Heart 2000; 83: 688-95.

[53] Moliterno DJ, Lange RA, Gerard RD, Willard JE, Lackner C, Hillis LD. Influence of intranasal cocaine on plasma constituents associated with endogenous thrombosis and thrombolysis. Am J Med 1994; 96: 492-6.

[54] Siegel AJ, Sholar MB, Mendelson JH, et al. Cocaine-induced erythrocytosis and increase in von Willebrand factor: evidence for drug-related blood doping and prothrombotic effects. Arch Intern Med 1999; 159: 1925-9.

[55] Steffel J, Iseli S, Arnet C, Luscher TF, Tanner FC. Cocaine unbalances endothelial tissue factor and tissue factor pathway inhibitor expression. J Mol Cell Cardiol 2006; 40: 746-9.

[56] Bacharach JM, Colville DS, Lie JT. Accelerated atherosclerosis, aneurysmal disease, and aortitis: possible pathogenetic association with cocaine abuse. Int Angiol 1992; 11: 83-6.

[57] Kolodgie FD, Virmani R, Cornhill JF, Herderick EE, Smialek J. Increase in atherosclerosis and adventitial mast cells in cocaine abusers: an alternative mechanism of cocaine-associated coronary vasospasm and thrombosis. J Am Coll Cardiol 1991; 17: 1553-60.

[58] Perron AD, Gibbs M. Thoracic aortic dissection secondary to crack cocaine ingestion. Am J Emerg Med 1997; 15: 507-9.
[59] Kolodgie FD, Wilson PS, Mergner WJ, Virmani R. Cocaineinduced increase in the permeability function of human vascular endothelial cell monolayers. Exp Mol Pathol 1999; 66: 109-22.

[60] Gan X, Zhang L, Berger O, et al. Cocaine enhances brain endothelial adhesion molecules and leukocyte migration. Clin Immunol 1999; 91: 68-6.

[61] Dressler FA, Malekzadeh S, Roberts WC. Quantitative analysis of amounts of coronary arterial narrowing in cocaine addicts. Am J Cardiol 1990; 65: 303-8.

[62] Su J, Li J, Li W, Altura B, Altura B. Cocaine induces apoptosis in primary cultured rat aortic vascular smooth muscle cells: possible relationship to aortic dissection, atherosclerosis, and hypertension. Int J Toxicol 2004; 23: 233-7.

[63] He J, Xiao Y, Zhang L. Cocaine induces apoptosis in human coronary artery endothelial cells. J Cardiovasc Pharmacol 2000; 35 $572-80$

[64] Green RM, Kelly KM, Gabrielsen T, Levine SR, Vanderzant C. Multiple intracerebral hemorrhages after smoking "crack" cocaine. Stroke 1990; 21: 957-62.

[65] Brzezinski MR, Spink BJ, Dean RA, Berkman CE, Cashman JR, Bosron WF. Human liver carboxylesterase hCE-: binding specificity for cocaine, heroin, and their metabolites and analogs. Drug Metab Dispos 1997; 25: 1089-96.

[66] Hearn WL, Flynn DD, Hime GW, et al. Cocaethylene: a unique cocaine metabolite displays high affinity for the dopamine transporter. J Neurochem 1991; 56: 698-701.

[67] Qiu Z, Morgan JP. Differential effects of cocaine and cocaethylene on intracellular $\mathrm{Ca} 2+$ and myocardial contraction in cardiac myocytes. Br J Pharmacol 1993; 109: 293-98.

[68] Woodward JJ, Mansbach R, Carroll FI, Balster RL. Cocaethylene inhibits dopamine uptake and produces cocaine-like actions in drug discrimination studies. Eur J Pharmacol 1991; 197: 235-6.

[69] Hart CL, Jatlow P, Sevarino KA, McCance-Katz EF. Comparison of intravenous cocaethylene and cocaine in humans. Psychopharmacology (Berl) 2000; 149: 153-62.

[70] Perez-Reyes M, Jeffcoat AR. Ethanol/cocaine interaction: cocaine and cocaethylene plasma concentrations and their relationship to subjective and cardiovascular effects. Life Sci 1992; 51: 553-63.

[71] Tacker DH, Okorodudu AO. Evidence for injurious effect of cocaethylene in human microvascular endothelial cells. Clin Chim Acta 2004; 345: 69-7.

[72] Jatlow P, McCance EF, Bradberry CW, Elsworth JD, Taylor JR, Roth RH. Alcohol plus cocaine: the whole is more than the sum of its parts. Ther Drug Monit 1996; 18: 460-4.

[73] Ascher EK, Stauffer JC, Gaasch WH. Coronary artery spasm, cardiac arrest, transient electrocardiographic Q waves and stunned myocardium in cocaine-associated acute myocardial infarction. Am J Cardiol 1988; 61: 939-41.

[74] Isner JM, Estes NAr, Thompson PD, et al. Acute cardiac events temporally related to cocaine abuse. N Engl J Med 1986; 315 : 1438-43

[75] Knuepfer MM. Cardiovascular disorders associated with cocaine use: myths and truths. Pharmacol Ther 2003; 97: 181-22.

[76] Schachne JS, Roberts BH, Thompson PD. Coronary-artery spasm and myocardial infarction associated with cocaine use. N Engl J Med 1984; 310: 1665-66.

[77] Tardiff K, Gross E, Wu J, Stajic M, Millman R. Analysis of cocaine-positive fatalities. J Forensic Sci 1989; 34: 53-3

[78] Wagner FA, Anthony JC. Into the world of illegal drug use: exposure opportunity and other mechanisms linking the use of alcohol tobacco, marijuana, and cocaine. Am J Epidemiol 2002; 155: 918 25

[79] Cryer PE, Haymond MW, Santiago JV, Shah SD. Norepinephrine and epinephrine release and adrenergic mediation of smokingassociated hemodynamic and metabolic events. $\mathrm{N}$ Engl J Med 1976; 295: 573-7.

[80] Nicod P, Rehr R, Winniford MD, Campbell WB, Firth BG, Hillis LD. Acute systemic and coronary hemodynamic and serologic responses to cigarette smoking in long-term smokers with atherosclerotic coronary artery disease. J Am Coll Cardiol 1984; 4: 964-71.

[81] Thomas CB, Bateman JL, Lindberg EF, Bornhold HJ. Observations on the individual effects of smoking on the blood pressure, heart rate, stroke volume and cardiac output of healthy young adults. Ann Intern Med 1956; 44: 874-92. 
[82] Moreyra AE, Lacy CR, Wilson AC, Kumar A, Kostis JB. Arterial blood nicotine concentration and coronary vasoconstrictive effect of low-nicotine cigarette smoking. Am Heart J 1992; 124: 392-7.

[83] Quillen JE, Rossen JD, Oskarsson HJ, Minor RLJ, Lopez AG, Winniford MD. Acute effect of cigarette smoking on the coronary circulation: constriction of epicardial and resistance vessels. J Am Coll Cardiol 1993; 22: 642-7.

[84] Winniford MD, Wheelan KR, Kremers MS, et al. Smokinginduced coronary vasoconstriction in patients with atherosclerotic coronary artery disease: evidence for adrenergically mediated alterations in coronary artery tone. Circulation 1986; 73: 662-7.

[85] Zimmerman M, McGeachie J. The effect of nicotine on aortic endothelium. A quantitative ultrastructural study. Atherosclerosis 1987; 63: 33-41.

[86] Reinders JH, Brinkman HJ, van Mourik JA, de Groot PG. Cigarette smoke impairs endothelial cell prostacyclin production. Arteriosclerosis 1986; 6: 15-23.

[87] Sonnenfeld T, Wennmalm A. Inhibition by nicotine of the formation of prostacyclin-like activity in rabbit and human vascular tissue. Br J Pharmacol 1980; 71: 609-13.

[88] Daggett RB, Haghighi P, Terkeltaub RA. Nasal cocaine abuse causing an aggressive midline intranasal and pharyngeal destructive process mimicking midline reticulosis and limited Wegener's granulomatosis. J Rheumatol 1990; 17: 838-40.
[89] Bezmalinovic Z, Gonzalez M, Farr C. Oropharyngeal injury possibly due to free-base cocaine. N Engl J Med 1988; 319: 1420-1.

[90] Murray RJ, Albin RJ, Mergner W, Criner GJ. Diffuse alveolar hemorrhage temporally related to cocaine smoking. Chest 1988; 93: 427-9.

[91] Kline JN, Hirasuna JD. Pulmonary edema after freebase cocaine smoking--not due to an adulterant. Chest 1990; 97: 1009-10.

[92] Susskind H, Weber DA, Volkow ND, Hitzemann R. Increased lung permeability following long-term use of free-base cocaine (crack). Chest 1991; 100: 903-9.

[93] Roth D, Alarcon FJ, Fernandez JA, Preston RA, Bourgoignie JJ Acute rhabdomyolysis associated with cocaine intoxication. N Engl J Med 1988; 319: 673-7.

[94] Singhal PC, Rubin RB, Peters A, Santiago A, Neugarten J. Rhabdomyolysis and acute renal failure associated with cocaine abuse. $\mathrm{J}$ Toxicol Clin Toxicol 1990; 28: 321-30.

[95] Chasnoff IJ, Burns WJ, Schnoll SH, Burns KA. Cocaine use in pregnancy. N Engl J Med 1985; 313: 666-9.

[96] Acker D, Sachs BP, Tracey KJ, Wise WE. Abruptio placentae associated with cocaine use. Am J Obstet Gynecol 1983; 146: 2201.

[97] Handler A, Kistin N, Davis F, Ferre C. Cocaine use during pregnancy: perinatal outcomes. Am J Epidemiol 1991; 133: 818-25.

Received: April 16, 2008

Revised: April 23, 2008

Accepted: April 25, 2008

(C) Bansal and Morgan; Licensee Bentham Open.

This is an open access article licensed under the terms of the Creative Commons Attribution Non-Commercial License (http://creativecommons.org/licenses/by-nc/3.0/) which permits unrestricted, non-commercial use, distribution and reproduction in any medium, provided the work is properly cited. 